\title{
RIVER DEVELOPMENT AS A SUSTAINABLE GEO-TOURISM WITH A PARTICIPATORY STAKEHOLDER APPROACH
}

\author{
Mohamad Sapari Dwi HADIAN* \\ University of Padjadjaran (UNPAD), Faculty of Geological Engineering, Jl. Bandung-Sumedang KM 21 Jatinangor, Indonesia, e-mail: sapari@unpad.ac.id \\ Bombom Rachmat SUGANDA \\ University of Padjadjaran (UNPAD), Faculty of Geological Engineering, \\ J1. Bandung-Sumedang KM 21 Jatinangor, Indonesia, e-mail: bombom.rachmat.suganda@unpad.ac.id
}

Ute Lies Siti KHADIJAH

University of Padjadjaran (UNPAD), Master of Sustainable Tourism School of Postgraduate,

Jl. Bandung-Sumedang KM 21 Jatinangor, Indonesia, e-mail: ute.lies@unpad.ac.id

Rully Khairul ANWAR

University of Padjadjaran (UNPAD), Faculty of Communication Sciences, Jl. Bandung-Sumedang KM 21 Jatinangor, Indonesia, e-mail: rully.khairul@unpad.ac.id

Citation: Hadian, M.S.D, Suganda, B.R., Khadijah, U.L.S., \& Anwar, R.K. (2021). RIVER DEVELOPMENT AS A SUSTAINABLE GEO-TOURISM WITH A PARTICIPATORY STAKEHOLDER APPROACH. GeoJournal of Tourism and Geosites, 34(1), 155-163. https://doi.org/10.30892/gtg.34120-631

\begin{abstract}
This study initially carried out mapping geodiversity along the Citarum River area and identified the potential for Citarum geotourism, mapping stakeholders in Citarum geotourism. Of the nine sectors (Upper Citarum Zone) of the Citarum River Area mapped, one village can represent the geotourism area, namely Cibeureum Village, Kertasari District, Bandung Regency. This research's research type is PAR (Participatory Action Research) with primary and secondary data collection. Meanwhile, data analysis uses qualitative and quantitative analysis methods (mixed method), content analysis, map analysis, geodiversity analysis, and is equipped with qualitative and quantitative descriptive analysis methods. The results of this study indicate that community participation has yielded benefits for local communities. However, many things need to be provided to the community from various skills to benefit all parties, including maintaining geodiversity sustainability in the geotourism area.
\end{abstract}

Key words: stakeholder participatory approach; Citarum River; Geodiversity; Geo-tourism; community benefits

$* \quad * * * * *$

\section{INTRODUCTION}

Sustainable development does not only prioritize activities that protect nature but promote the welfare of its people. Tourism activities are near related to sustainable development, especially in the relationship between abiotic, biotic, and cultural aspects, so the term geotourism emerged (Pereira et al., 2018; Dowling, 2013). Ecotourism activities can be carried out through individual tourist visits to geological sites or guided tours (Newsome and Dowling, 2010) via geotourism routes (Newsome et al., 2012), which can be reached by driving, cycling, and walking (Bouzekraoui et al., 2018). The involvement of the local community is very much needed in providing geotours, geo products, geo restaurants, and geo souvenirs (Farsani et al., 2011), of course with the support of the local government in providing infrastructures such as transportation, facilities and infrastructure for tourist attractions, and supporting facilities for geotourism through its territorial planning. These efforts are carried out and improving the economy and public knowledge of geology and aiming to meet geotourism destinations' needs.

The Citarum River flows from the upstream area of Mount Wayang, south of Bandung City, to the north and empties into the Java Sea. With a length of about $297 \mathrm{~km}$. Citarum is the longest and largest river in West Java Province. The Citarum River has a vital role in the community's socio-economic life, especially in West Java and Jakarta. Citarum River water is used as a source of raw water, agricultural irrigation, fisheries, a source for hydroelectric power for the supply of Java and Bali, and water supply for industrial acti vities. To conserve water resources and other natural resources in the Citarum River area, the development of geotourism can be an alternative in supporting sustainable development. In terms of existing geological diversity (geodiversity), the Citarum watershed area has geosite and geoheritage potential scattered in its scope. Geological heritage, as part of the geotourism component, promotes education and development aspects. Citarum geotourism development cannot be separated from the research program to restore the Citarum River.

According to Government Regulation no. 35 of 1991 concerning rivers, a river area is a unitary irrigation system resulting from developing one or more watersheds. River management must cover the entire river area. Furthermore, (Regulation of the Minister of Public Works and Public Housing Number 04 / PRT / M / 2015 concerning Criteria and Designation of River Basins, the Citarum River Basin is a National Strategic River Basin with River Basin Code: 02.06.A3. The Citarum River Basin consists of 10 districts and 2 Cities with the Citarum river into the main river. Further, CRB consists of 10 sub-Citarum include Sub Citarum Hulu, Citarik, Cisangkuy, Cikapundung, Ciwidey, Ciminyak, Cimeta, Cisokan, Cikaso, and Cikundul.

In 2019 a Research Program was prepared by the Citarum Research Center, Padjadjaran University, a strategic framework for restoring the Citarum River. The research program's elements include urban and community revisioning, design and engagement, and sustainability assessment and projection with indicators that include: 1) a water quality monitoring system Citarum. 2) Handling of wastewater and sanitation. 3) Collaborative waste management. 4) River discharge control. 5) Revitalization of the upstream sub-basin area. 6) Urban monitoring environment with community involvement. 7) Participatory multilevel watershed governance. 8) Increasing awareness of environmental laws at various levels. 9) Research SDGs. The Citarum River research program's direction is necessary to develop Citarum geotourism as sustainable development through a stakeholder participatory approach. The story of Citarum geotourism is prepared based on the water resources management strategy selected from the alternative plan contained in the water resources management pattern by the 
coordinating forum for water resources management in the river basin concerned. Citarum geotourism development as a form of sustainable tourism based on geodiversity through a stakeholder participatory approach is a comprehensive and integrated development prepared through public consultation. It involves the role of the community, business world, academics, and all parties related to the management of natural resources, including water resources in the Citarum River Basin. The various natural resources available in the Citarum river area are the essential capital for implementing sustainable development. This potential can be utilized for development activities in different sectors according to the national development program policies that use natural resources optimally for the people's welfare. By paying attention to preserving the environment's function and balance, geodiversity can be utilized to the fullest as a resource for scientific development and to support natural tourism objects with a geological perspective (Hjort et al., 2015). Geological diversity is the variability of the earth's surface materials, landscapes, and physical processes, for example, materials such as rock, soil, and water (Gray, 2011). Geological diversity is widely recognized for its scientific value and the substantial knowledge benefits it provides to society (e.g., records of past climate change, the evolution of life, and understanding of how Earth systems operate) (Gray, 2011; Gray et al., 2013).

In the context of nature conservation, geological diversity provides many essential services for geological diversity, including providing a substrate and mosaic landforms for habitat development (static aspects), as well as soil formation (biogeochemical and water cycles, and geomorphological processes; for example, water flow regimes, sediment supply, erosion, and rainfall) for habitat maintenance (dynamic aspects). These values are now embedded in the service ecosystem concept (Millennium Ecosystem Assessment) (Board, 2005). Without the contribution of biodiversity, many ecosystem services essential for life on earth would become extinct or require much more expensive technological alternatives. Geological diversity underlies and provides most ecosystem services (Gordon and Barron, 2013; Gray, 2011; Gray et al., 2013). It also provides additional inseparable items (e.g., minerals, aggregates, and fossil fuels) that are typically considered nonrenewable capital assets (Gray et al., 2013). The value of biodiversity is classified into five groups that can benefit human life (Gray, 2004; Melelli, 2014): (1) Intrinsic value, independent of social evaluation, is also called scientific value. (2) Cultural values are related to geomythological aspects, historical and archaeological aspects, and spiritual and religious aspects. (3) Aesthetic value refers to the visual and non-visual attractiveness of biodiversity, which involves psychological effects on humans. The amount of biodiversity is also significant for geotourism activities. (4) Economical and functional values are useful for using mineral resources such as fuel and construction materials, utilization of landscapes, and utilization of geodiversity, respectively geo-heritage, for geotourism activities. (5) The value of research and education is related to understanding the origin of life and landscapes, landscapes and climate evolution, and paleogeographic reconstruction.

Why geodiversity is so essential, in the last decades, there has been an appreciation of the values of a broader range of geodiversity and its relation to landscape and biodiversity conservation, economic development, climate change adaptation, sustainable land and water management, historical and cultural heritage, and health community and well-being (Gordon and Barron, 2013; IUCN, 2012). Geological diversity is an important starting point for ensuring biodiversity and natural diversity as a whole. Geological diversity is a geological component that functions as a historical trace of the earth's formation. Geotourism is tourism services and facilities for tourists in obtaining knowledge and understanding of the geology and geomorphology of a geological site (Hose, 1995). In Indonesia itself, the publication of geotourism has been around since 1999 by the Geological Survey Center (Brahmantyo, 2013), which defines geotourism as a tour activity that utilizes all aspects of geology, especially non-living features such as landscapes, rocks, fossils, minerals, and waters, as well as the process of forming these geological features. Furthermore, geotourism is an element of commercialization for tourism activities, mostly based on geological factors (Sungkar and Brahmantyo, 2013).

Geotourism is a sector that emerges from sustainable tourism with global growth, and its formation is based on five main principles, the first three principles, 1) geological-based, 2) sustainable, and 3) educational, which are characteristic of the form of geotourism while the other two directions, 4) are beneficial for the local community, and 5) creating geo-tourist satisfaction, being ideal for all forms of tourism (Dowling, 2011). If properly designed and managed, the linkage between sustainable development and geotourism can provide economic, social, and environmental benefits to geotourism destinations. Sustainable development is a vehicle for creating jobs, stimulating wealth of geological resources, and providing social welfare benefits for the community (Olson and Dowling, 2018).

The General Assembly of the United Nations (UN) has designated 2017 as the International Year of Sustainable Tourism for Development and revealed that designing and managing tourism well can make a significant contribution to three dimensions of sustainable development, depending on the sustainable management of natural resources (Henriques et al., 2019). Sustainable development is a conceptual framework in global growth that represents a multidimensional phenomenon and includes much different human activity (Mihić et al., 2012), one of which is related to a long-term perspective on natural resources (Amir et al., 2015). As the primary source for geotourism, geological heritage is part of the holistic concept of protection, education, and sustainable development (Lazzari and Aloia, 2014). Furthermore, a geopark as a geotourism destination is a pioneer in ecotourism, stimulating socio-economic activities and sustainable development by attracting more and more geo-tourists (Farsani et al., 2011). Geotourism development is based on five main principles, the first three principles, 1) geological-based, 2) sustainable, and 3) educational, which are characteristic of geotourism while the other two directions, 4) benefit the local community, and 5) create satisfaction for geo tourists, is ideal for all forms of tourism (Dowling, 2011).

Table 1. Linkage of geo-tourism and SDGS, results of analysis (2018)

\begin{tabular}{|c|c|l|}
\hline $\begin{array}{c}\text { Principles of } \\
\text { Geo-tourism }\end{array}$ & $\begin{array}{c}\text { Sustainable } \\
\text { Development Targets }\end{array}$ & Linkage of Geo-tourism with SDGS \\
\hline $\begin{array}{c}\text { Geological- } \\
\text { Based }\end{array}$ & $\begin{array}{c}\text { Goals: } \\
6,13,14,15 .\end{array}$ & $\begin{array}{l}\text { Process elements and forms of geo-tourism attraction are fundamental elements of activities geo tourism, this } \\
\text { requires the management and protection of the earth's heritage, biodiversity, and culture, followed by educational } \\
\text { efforts, awareness, mitigation capacity, and adaptation to the impacts of climate change. }\end{array}$ \\
\hline Sustainable & $\begin{array}{c}\text { Goals: } \\
4,6,8,12,13,14,15,17\end{array}$ & $\begin{array}{l}\text { Encouraging the creation of a local economy, building community capacity, and conservation efforts for geological } \\
\text { and non-geological sites through education and cross-sector participation at local, national and global scales. }\end{array}$ \\
\hline Educational & $\begin{array}{c}\text { Goals: } \\
4,12,13\end{array}$ & $\begin{array}{l}\text { Through active and passive interpretations, local people receive education related to geological diversity, biodiversity and } \\
\text { cultural diversity, as well as an understanding of consumption patterns in geo tourists that are in harmony with nature. }\end{array}$ \\
\hline $\begin{array}{c}\text { Beneficial to } \\
\text { Local } \\
\text { Communities }\end{array}$ & $\begin{array}{c}\text { Goal: } \\
1,4,5,8,11,12,17\end{array}$ & $\begin{array}{l}\text { Job creation, education efforts, gender equality, promoting the culture of local communities, and protecting the cultural } \\
\text { heritage of their ancestors are of various benefits for the local community. In addition, there are also efforts to } \\
\text { increase awareness of integrated sustainable development between the community and various related stakeholders. }\end{array}$ \\
\hline $\begin{array}{c}\text { Geo-tourism's } \\
\text { Satisfaction }\end{array}$ & $4,11,12$, Good & $\begin{array}{l}\text { Interpretation provides an experience for geo-tourists, considering that experience is the main product of geo- } \\
\text { tourism activities. In addition, accessibility and supporting facilities for geo-tourism are other factors that can } \\
\text { create satisfaction for geo-tourists. }\end{array}$ \\
\hline
\end{tabular}

Meanwhile, suppose it is related to the Sustainable Development Goals (SDGs) (United Nations, 2015). In that case, the contribution of geotourism is in 11 SDGs destinations, which can be seen in Figure 8 with the following brief explanation: (1) Goal 1, local communities 
around the geotourism attraction have equal rights to various sources of income and management of natural resources and inheritance. (2) Goal 4, provide education for local communities and geo tourists to obtain sustainable development and appreciation and contribute to cultural diversity. (3) Goal 5, ensure women's participation and opportunities to take leadership in decision-making in social life and development. (4) Goal 6, protect and restore aquatic ecosystems, including mountains, forests, river swamps, watersheds, and lakes. (5) Goal 8, Encourage the local economy to develop geotourism that creates jobs, promotes culture and local products. (6) Goal 11, Strengthen efforts to protect and to safeguard natural and cultural heritage. Also, it provides accessibility facilities such as green open spaces and is friendly to people with disabilities. (7) Goal 12, Provide education and raise awareness of sustainable development through a lifestyle in harmony with nature. (8) Goal 13, increase knowledge, awareness, and capacity to mitigate and adapt to climate change impacts. (9) Goal 14, prevent and reduce all kinds of marine pollution and protect it sustainably. (10)

Goal 15, conserve, restore, and use freshwater and terrestrial ecosystems and prevent biodiversity extinction. (11) Goal 17, improve cooperation and local, regional, and international stakeholders' cooperation in sharing knowledge, ideas, and implementation.

\section{MATERIALS AND METHODS}

From its primary paradigm, action research methods are categorized into interpretive/naturalistic (qualitative) approaches. Qualitative methods can be used to reveal and understand something behind a phenomenon that is little, not yet known (Veal, 2017). This method can also be used to gain insight into something that is little known. By the explanation above and the research objectives to be achieved, the approach used in this study is a qualitative and quantitative research approach. The qualitative approach is directed at the setting and the individual holistically (intact). The qualitative approach in this research is used to obtain in-depth data. For this reason, researchers collect and analyze data on field findings and present them descriptively and the meanings they contain.

The type of research used in this research is PAR (Participatory Action Research), which means that research emphasizes the collaboration of actors and researchers to change situations or behavior, increase knowledge, and increase abilities. PAR is a study where the control is carried out together, both the researcher and the perpetrators. It can also be concluded that PAR is a study that actively involves all parties related to the research subject under investigation in assessing ongoing actions to make changes and improvements for the better.

Participatory Action Research (PAR) builds bridges to connect people (Lovell, 2009; McIntyre, 2007; Jenkins and Ito, 2015; Schuler and Namioka, 1993). This research seeks to develop practical knowledge in understanding social, political, environmental, or economic conditions. PAR is a participatory research and development method that recognizes social relationships and values the reality of our experiences, thoughts, and feelings. This research is looking for something to connect the research process to the process of social change. This research recognizes that the change process is a subject that can be researched. This research brings the research process into the circle of people's interests and finds practical solutions to common problems and issues that require joint action and reflection, and contributes to functional theory. In the study of participatory action, the fundamental principles of research are as follows: (1) The community must be involved in the entire research process, from problem formulation to a discussion about finding solutions to problems and interpreting findings; (2) The research team must be a combination of all elements that bring change; (3) The research process must be seen as part of the educational experience that seeks to build community needs and increase community awareness and commitment; (4) The process should be viewed as a dialectical process, dialogue over time, and not as a static image of a point in time; (5) The object must be the liberation of human creative potential and human resources mobilization for solving social problems.

This study's data collection method is divided into 2 (two) types: primary and secondary data collection. Primary data collection was carried out using observation, field surveys, and interview methods. This study's main source was to determine key sources and sources in this study by purposive snowball sampling, which was carried out from the central level to the local level. The secondary dat a collection method was carried out by surveying institutional data, such as various spatial planning and tourism at different regional groups. Also, other secondary data collected are statistical data that supports multiple analyzes conducted in this study.

This research uses qualitative and quantitative analysis methods, content analysis, geodiversity analysis (quantitative), and map analysis, and is equipped with a qualitative descriptive analysis method. The data and information obtained are then carried out by the data input process, data management, and data plotting and conversion. Furthermore, the data and information are assessed and tested on existing concepts and theories using qualitative and quantitative analysis procedures through Data analysis before being in the field, data reduction, data presentation, and conclusion drawing; qualitative conclusions will be completed through scoring as a representation of the findings quantitatively, both in drawing temporary conclusions and final conclusions. This is intended so that the qualitative data output does not cause multiple perceptions and can facilitate the communication of research results.

\section{RESULTS DISCUSSIONS \\ UPPER CITARUM}

Geological diversity is the main source of attraction for the sustainability of tourism activities, especially geotourism, in the Upper Citarum Zone. The distribution of geological diversity is supported by biodiversity and cultural diversity in the Upper Citarum Zone, making the area a Geotourism Destination. Geological diversity that has tourism facilities is used as a geotourism attraction, while those that are not supported by tourism facilities make it a geotourism resource. There are 40 geological diversity scattered in the Upper Citarum Zone. Geotourism potential in the Upper Citarum Zone is classified into Upstream Citarum Tourism Destinations, which includes five tourism areas based on the Upper Citarum Sub Watershed division. The tourism area includes 1) Upper Citarum Tourism Area, which includes 13 tourist attractions and 11 tourist resources; 2) Citarik Tourism Area, which includes ten tourist attractions and five tourist resources; 3) Cikapundung Tourism Area, which includes 23 tourist attractions and eight tourist resources; 4) Cisangkuy Tourism Area which includes five tourist attractions and seven tourist resources; 5) Ciwidey Tourism Area which includes seven tourist attractions and eight tourist resources. Meanwhile, in the Cikapundung and Ciwidey sub-watersheds, tourism activities have been running well. This is indicated by the high tourist visits every weekend and long holidays. It will not be separated from time because one condition can not be considered but must compare two conditions for a particular purpose when analyzing a social change in society. There could be noticeable differences in a physical or non-physical object and now the object's condition in the past.

The system is complex, made up of different kinds of relationships, and separated by certain limits from the surrounding environment. Similarly, its complexity is also seen as a system if it is used in human society. Also, qualitatively a system is considered in certain segments of the society, such as economic, political, and cultural aspects. The creation of balance or shock, consensus, contention, harmony or strife, cooperation or conflict, and so on, comes from the interplay of the whole complex systems. Rural society is characterized by a strong inner feeling among members of the village community. A person is an inseparable part of the community in which he lives, with the characteristics of an agrarian society that is closely related to kinship compared to urban society. The life system of an agrarian society is 
generally grouped based on kinship, most of the agrarian communities live in agriculture, the society is homogeneous, such as in terms of livelihood, religion, and so on. Agricultural societies are often characterized by farming methods using traditional tools such as hoes, sickles, and others. The mode of production carried out by agrarian societies in the economic sector is usually in agriculture and livestock in traditional ways. Natural resources are in the form of land, water, humans, which in the end, they need raw materials or nature to support life.

Likewise, what happened in Cibeureum Village, where one of the characteristics of rural communities is the high spirit of mutual cooperation. People always help each other in terms of togetherness, as expressed by Mustaqim, one of the farmers, he said that "people often do working together or a kind of collective voluntary work done by the people of Cibeureum Village to clean clogged waterways. Meanwhile, currently, Babakan Village people are starting to find it difficult to be invited to this social service because residents are willing to work socially if they receive cash rewards." (Interview with Mustaqim, 2020). The above statement shows that agrarian society is not stagnant. It develop and change like modern society, but the level of change felt by the people of Cibeureum Village feels slow for years, or it can be said that the trend of change is slow. The tendency to be modest in people's lives always occurs and is deeply rooted in society.

Cibeureum Village is a very large agricultural and plantation area, with the community's average population making use of this vast land to seek or supplement their daily income. The interview results by the researcher with a resident of Cibeureum Village, named Mustofa, said that "the condition of the people of Cibeureum Village is generally a livelihood as a farmer, from father to child. They start working after leaving school. According to him, farming has become a hereditary income from his parents' grandmother (Interview with Mustofa, 2020). With the good natural resources owned by Cibeureum Village, of course, many of the surrounding communities use this land to be used as agricultural and livestock land, with large areas of land, and not much land has been converted into tourism objects or other things. People rely on their land to find their daily needs. The researcher interviewed one of the farmers named Mustaqim. He said: "Before the emergence and development of tourism in Cibeureum Village, the majority of the people were farming, raising lives tock, but some people migrated to other cities to sell. Besides that, Mustaqim also said that the conditions of Cibeureum Village were not as similar." (Interview with Mustaqim, 2020). The interview results above show that Cibeureum Village people tend to work as farmers when they are still in an agrarian society. This was supported by the community's direct use of natural resources, as evidenced by the average number of farmers around 743 families. At this time, the people of Cibeureum Village had not experienced social change.

Because society in every development will always experience social changes, these changes occur slowly or quickly, planned, or unplanned. In general, the social changes that occur in society result from modifications to community life patterns that have been influenced so that social change occurs. In line with Herbert Spencer, humans and society, including cultures that experience development through certain stages, change from simple forms to more complex ones and finally become perfect with various industries.

This was reinforced by the results of an interview with one of the farmers named Yanto, he said that: "The condition of the people of Cibeureum Village before tourism did not change much in the community, the community only farmed, raised livestock, and not many people in Cibeureum Village were utilized by tourism (Interview with Yanto, 2020).

\section{THE STATE OF THE COMMUNITY BEFORE THE TOURISM INDUSTRY}

With the explanation above the results of interviews conducted by researchers during field observations, the researchers found several aspects that occurred in the community when the community was in an agricultural society, including social and economic aspects.

Rural communities are people who have a strong inner bond with other members of society. The village community will feel that they are an inseparable part of the community where they live, with this assumption that they will always make sacrifices for other communities because they feel that fellow community members should love, respect, and have the right to be responsible together towards peace and happiness in society. One of the characteristics of the Village community is a very intense communication pattern. This also occurs in the Cibeureum Village community, which occurs between community members that are well established before changes that occur in the community with the tourism industry. As for the form of communication that the researcher explored in a resident named Supriatin, he said that: "In terms of communication that occurs in Cibeureum Village, it is interpersonal in which communication is carried out verbally and faceto-face from one person to another. They still have a strong working-together spirit with the characteristics of the village community, cleaning the sewers or something else." (Interview with Supriatin, 2020). Indirectly, this study's findings show that the state of the Cibeureum Village community still retains its original character as a community where each resident still has a clear sense of belonging and responsibility.

In addition to the form of communication that researchers explore from the Cibeureum Village community, there are still many things done by the community in the social aspect. One of them is that the community is still not empowered by tourism, the existence of tourism evidences this, the community has begun to be properly empowered by tourism. When they were still in an agrarian society, Cibeureum Village people generally had high school education and immediately jumped in to help their parents farm. There were still many unemployed teenagers, starting from youth organizations who did not have a clear commu nity direction.

The researcher interviewed one of the cadets of Cibeureum Village named Rizky, he said that: "The conditions before the development of tourism that emerged in Cibeureum Village, teenagers only relied on farmers after graduating from school, there were a lot of young people who did not have jobs, and Karang Taruna is only limited to associations without any clear direction. The community is also difficult to empower because they are confused about empowering other communities. After all, there is no input from others, such as income from tourism after tourism." (Interview with Mustofa, 2020).

The activities and conditions of the people of Cibeureum Village when the conditions of the community were agrarian were not much different from the examples of rural communities in general. As the author examined in the results of the field research conducted, it could be said that the economic level of the Cibeureum Village community at that time was middle to lower because the number of landowners and farm laborers was very different, the people in Cibeureum Village did not change much in terms of their livelihoods depending on They sell agricultural products, livestock, plantations, the results of land processing directly to the market or to other collectors because not many lands have been converted into tourism land and there are no other jobs besides farming and opening small businesses. To increase or increase the economic output of the people of Cibeureum Village, the community only depends on agriculture because, at that time, tourism was not yet developed, and there were not many people who worked in the tourism or handicraft sector at that time. Because the majority of the people of Cibeureum Village usually focus more on farming, such as growing chilies, cabbage, tomatoes, and cassava.

Researchers interviewed a farmer as well as a vegetable medicine trader in Cibeureum Village. Ade, he said: "The condition of the people of Cibeureum Village is not much different from now, it's just that some farmers and farmland have now been converted into tourist areas. Also, some people have migrated to Bandung City or Subang Regency, they have migrated to sell medicinal vegetables" (Interview with Ade, 2020). From the above statement presented by one of the traders, the results of the interview. We can know that the condition of the people of Cibeureum Village is the same as the community in general in terms of economic aspects, not much different from the people of Suntenjaya Village, Wangun Harja Village, which is close to Cibeureum Village, this can be proven by the number of farmers around 743 
families and total farm laborers 1821 people. In this condition, the community does not experience many changes that occur in terms of livelihoods in Cibeureum Village, with tourism that has not developed as it is now, of course at that time it has not had much impact on Cibeureum Village, the community still relies on existing natural resources to support the economy of the community.

\section{SOCIAL AND ECONOMIC CHANGE}

Society is constantly changing at all levels of its internal complexity. At the macro level, there are economic, political, and cultural changes, at the meso-level there are changes in groups, communities, and organizations. At the micro-level, there are changes in individual interactions and behavior. Society is not a physical entity but interrelated in a double manner. As Edward Shils (2011) said, culture is a phenomenon between periods, culture is incarnated not by a moment 's life. But it's just over time. It's time-incarnation. Society operates from past to past to future. His involvement goes through a transition between what happened and what happens. In today's culture, there are past factors, traces, and traces, and seeds of future promise. Society's production existence means that the previous step is directly related to the current step as a causal requirement deciding the next phase. In human society, social change or gradual change is common among humans, as Herbert Spencer said that evolution's general law underwent special treatment. The mechanism of social evolution is based on three rules. First, it contains inequality of uniformity, inequality of homogeneous populations. Human individuals are basically different in terms of innate talents, individual experiences, and environmental conditions in which they live. Humans cannot survive in the form of a homogeneous mass without the emergence of differentiation of roles, functions, power, wealth. Second, there is a tendency for stronger role specialization inequality, power disparities, and wealth differences to deepen. As a result, the initial differentiation develops gradually and accumulatively. Third, because people in the same position (role, prestige, wealth) tend to gather together.

This mechanism produces a series of inseparable stages in human history, starting from the simple stage of society, the activities of all its members are the same without political organization, through the complex society stage, there is a division of labor between individuals and the division of functions between societies begins to emerge, then enters a more complex stage of society has a constitution and permanent laws to the most complex stage of the civilization of social unity. The term tourism in recent years has become a hot topic of conversation among the public. Tourism is considered a new industry in Cibeureum Village, which has been proven capable of spurring rapid economic growth. Tourism is present in Cibeureum Village by displaying the beauty and uniqueness of tourism. The presence of tourism in Cibeureum Village has succeeded in changing the economy of the people who are directly involved in the tourism industry, which started only by farming, people began to dare to enter the tourism industry, began to take a position as workers, build hotels or build their tourism.

The rapid development of tourism in Cibeureum Village has succeeded in increasing the local community's standard of living. According to Herbert Spencer, the development of society is a process of continuous growth and change. Social evolution is a series of long-lasting social changes in society, starting from a homogeneous and simple group or society, gradually becoming a more advance d community group, and finally becoming a more complex society. Likewise, what happened in Cibeureum Village, the community began to experience a gradual change from an agrarian society to an industrial society from a simple society to a complex society. Changes that occur due to the development of tourism objects in Cibeureum Village are starting to be felt by some people in Cibeureum Village, starting from the social aspect to the economic aspect, the surrounding community has felt the changes.

The emergence of tourism in Cibeureum Village has led the community towards a more modern and more complex change. Tourism that is developing in Cibeureum Village includes tourism Situ Cisanti, Mulberry Hills, Fairy Garden. The three tourists are part of the The Lodge Group in Cibeureum Village. The three tourists are part of the Situ Cisanti Group in Cibeureum Village, which was originally established only for tourism Situ Cisanti in 2007, but time was passing, and visitor enthusiasts were booming at that time. The results of an interview conducted on one Situ Cisanti worker named Edik, he said that: "Situ Cisanti is a sustainable tourism environment. Because at first, Situ Cisanti was established not for tourism but only for a place to rest, the owner of Situ Cisanti himself who comes from Garut. However, the development of the era and the mass media in Situ Cisanti seems to be growing rapidly, according to Edik, this is part of nature's reciprocity to us if we want to protect the environment. And now what the community feels with the development of tourism is welcomed by the people themselves. (Interview with Edik, 2020). From Edik's explanation above, we can know that the development of tourism in Cibeureum Village has a good impact on the Cibeureum Village community's social changes because, according to him, around $90 \%$ of workers in tourism are originally residents of Cibeureum Village. Tourism is growing rapidly, assisted by social media, besides that, each existing tourism object presents a different view. Like Situ Cisanti, tourism provides Sky swing, hang gliding, camping, hot air balloon, sky tree. The five places present beautiful views to just take pictures and refresh the eyes. Mulberry Hills tourism is more dominant to tourist inns, there are many villas and beautiful scenery too. Meanwhile, Fairy Garden tourism provides a location for children's education that is good for children's development, such as many small children's games.

Of course, from the growing development of tourism in Cibeureum Village, the transition from an agrarian society to a tourism industry community has had a good impact on society both in terms of social and economic aspects. The people of Cibeureum Village have felt changes that have an impact in both positive and negative directions. But all of that is a natural thing in the social change that occurs.

Tourism growth in Cibeureum Village started around 2007 until now. This growth of tourism has changed people's lives. From a simple society to a more dynamic society, close community ties and tourism growth began undergoing changing changes. Once high in society, the importance of cooperation has now changed its importance to something that can be traded for material value, one of which is because the group has begun to be busy with the tourism sector's work activities.

However, it is experiencing changes in a negative direction, there are also many impacts on the community. The researcher interviewed one of the Situ Cisanti tourism employees who was originally a local resident of Cibeureum Village named Mustofa. He said that: "The RW 15 community very welcomes the development of Situ Cisanti tourism because Situ Cisanti entrusts tourism management to the in digenous people of Cibeureum Village, equally." On average, Situ Cisanti employees, almost $80 \%$, involve youth organizations and the surrounding community. In terms of the social aspects that are felt directly by the community, the direct empowerment of the tourism sect or and the management of youth organizations so that youth organizations have clear directions and goals, youth organizations are starting to be able to pay teachers teacher and pay for cleaning the garbage in the Cibeureum Village area. Also, Mustofa said that school children now do not directly help their parents but try to join the tourism industry in Cibeureum (Interview with Mustofa, 2020).

With so many tourism developments in Cibeureum Village, there have been many changes in the community's condition, especially influencing tourism adults and empowering the Cibeureum Village waste bank to make Cibeureum Village comfortable the tourism developments that occur in the area. It is in line with what Herbert Spencer said that every human being will always change quickly or slowly. Social evolution is so closely related to society. It could change from a simple community to a complex one, from a primitive community to a modern one. It is felt directly by Cibeureum Village people from the change of an agrarian society to a touris $m$ industry community. According to the interview results with a tourism worker named Edik, he said: "There are many social changes that occur in 
Cibeureum Village because, according to him, every tourist who visits the tourism location not only brings money but also brings rubbish. Cibeureum Village has a lot of garbage scattered about. Still, on the other hand, this has been anticipated by the youth organization because the tourism management team is working with the youth organization, the youth organization fund empowers community members to build waste processing so that the tourism area looks clean. (Interview with Edik, 2020). From Edik's explanation above, of course, the emergence of the development of the tourism industry that has emerged in Cibeureum Village greatly affects the community directly, with the growing tourism, it certainly requires a lot of workers, this is felt directly by the people of Cibeureum Village, especially new teenagers. After graduating from school, they are not bothered by the difficulty of finding a job, because tourism also empowers people who have the skills and willingness to be channeled towards tourism. It is felt directly by Karang Taruna.

The authors' results during an interview with one of the Youth Organization named Hambali, he said that: "This youth organization is in the form of a partnership with the Karang Taruna tourism in the form of a social organization in the community. It is not like the mass organizations that exist in tourism. According to him, mass organizations in the community, especially in tourism, only ask for detrimental things to tourism without a clear contribution, such as youth organizations in partnerships with tourism. (Interview with Hambali, 2020)

With the presentation of one of the Karang Taruna presentations above, we can know that how the tourism side manages the community directly, this is what makes tourism in Cibeureum Village last until now, because of its openness and trust in the community to make the community a direct part of the community. In addition to helping the people of Cibeureum Village in matters relating to society, tourism also helps the Cibeureum Village Government emphasize poverty and unemployment in Cibeureum Village. Nearly most Cibeureum Village people make their livelihoods mostly in the agricultural sector before the tourism industry is growing. Over a long period, there has been a change in Cibeureum Village due to the tourism industry. The basic needs that continue to increase make people think in a more advanced direction to meet more needs. Society also changes in terms of livelihoods from agrarian to the tourism industry.

\section{BUSINESS OPENING AROUND TOURISM LOCATIONS}

Community efforts to improve the economy include opening Bandung specialty food stalls, handicrafts, hotels to home culinary delights. As expressed by Fitri as a trader in the tourism area, "Thanks be to God, with the existence of tourism which is quite famous in the area of Bandung, especially Cisanti, this makes tourists want to enjoy the beauty of nature by coming to bring their families and partners to just have recreation to tourist attractions. It was welcomed by traders because the more visitors who came, the greater the merchandise's chance to run out quickly. With merchandise that runs out quickly, it helps to increase the yield of income (Interview with Fitri, 2020).

Apart from traders, residents also positively impact the development of tourism in which residents' houses are used as parking lots when the increasing number of visitors coming to tourism places is very profitable to simply increase their daily livelihoods. People of Cibeureum Village have experienced a shift in employment, such as a shift in livelihoods from farmers to the tourism industry, patterns of interaction with outsiders, changes in income levels, and changes in facilities and infrastructure. According to Sztompka, society is constantly changing at all levels of its internal complexity. In sociological studies, change is seen as dynamic and linear. In other words, change does not occur linearly. In general, social change can be defined as shifting or changing the structure or order in society to get a better livelihood.

\section{WORKING IN TOURISM INDUSTRY}

At first, in the Cibeureum Village community, many of the people did not have a job, many of them after graduating from school, were unemployed because of the difficulty of finding employment, but after the tourism industry was growing in Cibeureum Village, it could reduce unemployment because tourism managed the people of Cibeureum Village to work together as workers in tourism.

As Ridwan expressed, one of the tourism employees in Cibeureum Village said: "with this tourism, he can work, because previously he only worked as an employee of a cafe far from his house. This is certainly very helpful with tourism, especially in terms of distance to work with a clear income (Interview with Ridwan, 2020). As explained by Ridwan, the development of tourism has an impact on increasing economic change. With the existence of tourism, many people work as part of tourism members. From those who do not work to become workers from initially an agrarian society, some have shifted to the tourism industry, the availability of jobs, and increased income. The tourism sector has made a lot of assistance to the direct community, such as the construction of shops around the tourism object Situ Cisanti, from the construction, was given directly by Situ Cisanti, the salaries of the Koran teachers and cleaning money were borne by the tourism sector, which made the community comfortable with the presence of tourism. As Taufik stated as a trader in the tourism area, he said: "Actually, he is a farmer, but when the tourist Saturdays are busy, he uses his spare time to sell around the tourist area. Also, he said that by selling, he could add more income (Interview with Taufik, 2020.

From the interview results, it can be seen that the Cibeureum Village community's efforts in improving the economy to meet their daily needs not only from agricultural products but the community can participate in developing the tourism industry in Cibeureum Village. This can be seen from the interview results above that many people in Cibeureum Village are taking advantage of the growing development of tourism, the nature of the community starts to shift from a homogeneous group to a heterogen eous group where many jobs can be done, not just farming. Such as opening shops, stalls, selling souvenirs, and working directly from the tourism industry. Public knowle dge about how to cultivate opportunities with the growing development of tourism can be quite good because people are willing to work together with tourism. Of course, this situation is very beneficial for the people of Cibeureum Village in increasing their income. In addition to having an impact on increasing income, with the development of tourism, it helps the village government to reduce poverty by increasing employment opportunities. This can be proven by the large number of tourism workers who are native to the Cibeureum Village community, apart from people who work in tourism, the local community also takes advantage of other opportunities by making their home page a parking lot for tourist visitors. The author also interviewed a resident who worked as a parking manager and worked in the tourism section named Edik, who said: "Before developing tourism in Cibeureum Village, he worked as a farm laborer and sold agricultural medicines in Subang. However, when tourism grew rapidly, he returned to his village to work as part of a tourism worker (Interview with Edik, 2020).

From the results of the interview above that the author has done as a step towards taking data from the people of Cibeureum Village, we can find out that the growing tourism industry brings benefits to society in terms of economic improvement, this is felt by traders, workers, and youth organizations that are actively involved in managing tourism.

\section{THE IMPACT OF THE TOURISM INDUSTRY}

The tourism activities that are so complex include all aspects of life that directly impact the community's environment's sustainability. The impact is very felt for those who live around tourist objects and are directly involved in tourism activities. The impact of tourism development is in the form of positive and negative impacts. Before tourism developed, most of the people of Cibeureum Village worked as farmers, breeders, but after the development of tourism, the local people began to switch their livelihoods as tourism 
managers. According to the community, working in tourism is quite promising in increasing income compared to just being a farm laborer. According to Edik, the development of tourism also provides employment opportunities for local youth who do not continue their schooling to work, so tourism impacts employment for Cibeureum Village people. Tourism economic activity is an activity that can have a multiplier effect, which can trigger the growth of other economic activities in some regions. Starting from here, it can be explained that the tourism industry seems to be the driving force for the growth of other supporting industries. The main sectors in tourism, such as marketing, transportation, accommodation, supporting sector views, are attractive for recreation.

The growth of tourism support sectors in Cibeureum Village. Researchers have observed it since the boom in the community around 2015, infrastructure and facilities are increasingly mushrooming in the Situ Cisanti area, such as the number of stalls, food vendors, and hotels that have started to appear. Tourism also provides women with socio-economic opportunities by empowering PKK mothers with programs collaborating with tourism in Cibeureum Village. Apart from being empowered in social organizations, women in Cibeureum Village are also empowered as workers in restaurants to not depend on the husband's income.

Also, tourism has an impact on the development of people's mindsets. Local communities, especially those directly involved with tourism, will carry out social interactions with tourists from diverse cultural backgrounds. So that automatically, people's insight into the outside world will increase. The development of a public mindset is reflected in the community's awareness, the more parents who send their children to college, the more they realize that the times have made education a primary need that must be fulfilled.

On the way, tourists to tourism in Cibeureum Village are their reasons for visiting the area, namely tourist attractions, both natural, providing beautiful scenery and others. Cibeureum Village, a very beautiful Perhutani attraction, has charm for tourists from domestic and foreign tourists. Seeing the increasing number of visitors from various regions reaching 10 thousand people per day, this was taken advantage of by the people of Cibeureum Village. This moment is used as money by the people of Cibeureum Village, such as making their house land used as a parking area or leasing it to be used as a selling location by small traders, because many of the people become impromptu sellers when the number of tourists increases. Because moments like this help the community in improving the community's economy. The nature of tourism, which is open and directly touches the community, is very vulnerable to impacting society's social changes from various aspects of life. The impact of tourism is usually more focused on local communities who live near tourism objects. In addition to the positive impacts mentioned above, tourism as a free activity often negatively impacts local communities.

The increasingly individualistic nature of the community as a result of tourism has now begun to appear in the Cibeureum Village community where they have begun to think that working and making money is much more important than having to interact and spend time doing mutual cooperation, which is decreasing, different from the past where the intensity of the community to work equal very high.

The ease of getting a job in the tourism sector that does not require a lot of expertise for workers, it is feared that the local people of Cibeureum Village think that higher education is not too important, because of the cooperation between tourism and the people of Cibeureum Village which makes $90 \%$ of them as tourism employees. One form of relationship between local people and tourists is in mass-tourism, which means that there is nothing spontaneous between tourists and local people. But most of them have been arranged in tour packages by travel agents. Tourism activity is an activity with an economic purpose, which means that employment in tourism is only for economic purposes, which means that tourism increases economic interests in making a living. Therefore, the interaction between local people and tourists with tourists is more of an economic transaction. As happened in Cibeureum Village, the development of tourism has changed the relationship between the community and tourists, the form of hospitality that was originally purely on a cultural basis has now turned into commercialized hospitality. The change in commercialized hospitality is evidenced by the researcher's experience in the field while in the tourism area of Cibeureum Village. That what researchers see tourism managers and tourists only communicate that is beneficial is no longer coming purely from ourselves. Another negative impact that developed after the emergence of tourism felt by the people of Cibeureum Village was congestion because initially, this tourism was not a setting to actually be used as a tourism object but only to be used as a resting place for landowners. Still, a large area of land and with the concept of a beautiful environment, it invites the curiosity of visitors to come to visit tourism, this is what makes managers and the community not ready to prepare a large parking area, because at that time the tourists who come can reach 15,000 people with an average number.

It is what creates new problems in Cibeureum Village with frequent traffic jams, due to the congestion that occurs certainly affects farmers and cattle breeders, farmers who sell their crops experience delays which make their vegetables less fresh, while bre eders experience the same thing with farmers because they wanted to sell the squeezed milk but were blocked by the traffic jams they used to take.

However, this has been quickly resolved by the tourism manager, because basically with the arrival of tourist s who come, it is their own desire without an invitation letter. Therefore, the tourism management collaborates with youth organizations to solve the root of the problem that occurs in Cibeureum Village. Karang Taruna is assigned partly to open roads for vegetable cars and milk cars that want to cross the road. They are escorted by Karang Taruna until the end of the congestion; besides that, tourism also provides transportation services from outside tourism to reduce the volume of vehicles arriving at tourist attractions. From the interview results with the tourism manager named Edik, the researcher said that the development of the tourism industry in Cibeureum Village, apart from having a positive impact, also negatively impacted. Because the life of the tourism industry demands cultural changes that always have a negative impact, this negative impact does not mean it cannot be resolved, but it takes time and openness from those who feel aggrieved by the involvement of tourism, such as farmers and ranchers who feel the negative impact of tourism. However, the tourism management can resolve this by collaborating with youth organizations to unravel congestion and pave the way for farmers who want to pass (Interview with Edik, 2020).

From the explanation above, we can see that the negative impacts of Cibeureum Village can be overcome directly by the tourism manager due to the management's openness with the community, which has gone well until now. The informants felt this after in terviewing researchers during field observations. In an open and barrier-free world of tourism, all elements of culture easily join human life. Meetings between the local community and visitors seem to have a high level of tolerance, so as not to easily cause tensions between the surrounding community and visitors. However, it is feared that this openness attitude will harm Cibeureum Village residents' generation, even though residents have not felt it because of the many cultures that have entered Cibeureum Village. Tourism, as McKercher puts it, carries investment disproportionately because it focuses more on benefit centers, not cost centers (McKercher, 1993). Following what happened in Cibeureum Village, this theory says that tourism is based more on benefits alone. Still, attention to its bad impact on touri sm has not received much attention from both the government and the local community. It can be seen from the problems surrounding tourism goods, such as the amount of waste, although currently a waste bank management facility has been built.

\section{THEORY OF SOCIAL DEVELOPMENT}

Social change always has positive and negative impacts. Therefore, in responding to change, wisdom and in-depth understanding of the values, directions, and strategies are needed following the change's nature. Social change is part of cultural change; social change includes 
changes in age differences, birth rates, and a decrease in the sense of kinship among community members as a result of urbanization and modernization. Change is often faced with value systems, norms, and some supporting ideas. By communication media, changing the social, political, economic, educational, and cultural systems. The theoretical analysis that the researchers conducted in Cibeureum Village regarding the agrarian society's socio-economic changes with the tourism industry uses Herbert Spencer's classic theory of social evolution. Evolution also describes how society develops from a primitive society to an advanced society, the theory of evolution also combines a subjective view of values and the ultimate goal of social change. These changes occur gradually and slowly, which initially are simple and then turn into modern ones. At the stage of evolution, theorists regard society as the development of simple forms into complex forms, they believe that societies at a more advanced stage of development will be more progressive in other societie s. The theory of evolution tends to be ethnocentric because they consider modern society to be superior to the previous society. Social evolution is a series of social changes in a society that lasts for a long time, starting from a simple and homogeneous ethnic group or society, gradually becoming a more advanced ethnic group or society, and eventually becoming a complex modern society.

Cibeureum Village is a village that has experienced changes in its society. This change is said to be a social evolution like what is Herbert Spencer's theory, the people of Cibeureum Village have experienced a change into a more advanced society, they feel a significant impact from the changes that occur, they switch from an agricultural society to an industrial society, the amount of land is converted into a tourist area. Herbert Spencer describes this as a primitive society or a simple society that has shifted towards more complex society and become the society it aspires to. The changes that occurred in Cibeureum Village were not only about the livelihood sector. With the increasing number of job vacancies available, of course, it helps the people of Cibeureum Village reduce poverty and ensure the community's standard of living. This is done by the community so that it becomes a complex society and eventually becomes perfect. With the flow of changes occurring in the community that has brought the people of Cibeureum Village towards a more complex society characterized as a modern society, society has begun to change from a homogeneous to heterogeneous society, this is due to the impact of the growing tourism industry that occurs in Cibeureum Village.

The results of the authors' findings when research in the field of evolution in society do occur through various sectors, Cibeureum Village realizes that the changes that occur in society due to tourism certainly have a social and economic impact on the community, many people have begun to switch to work in tourism and tourism brings a positive impact in society so that the community will always maintain the existing tourism in Cibeureum Village and still exist because tourism really helps the community, especially in terms of economic improvement. The people of Cibeureum Village did this in order to create a dreamed community like what Herbert Spencer mentioned.

The community of Cibeureum Village is a village where the average livelihood of the community is a farmer. It is due to the large number of natural resources that can be processed by Cibeureum Village people. When changes occur, both social and economic changes after tourism change part of the community's work from homogeneous to heterogeneous groups because the community switches from an agricultural society to the tourism industry, it can be seen from the results of the author's research at the time in the field where there have been many kinds of work done by the community. There is already a specialization of work, such as the characteristics of modern society, this has happened since the existence of the tourism industry in Cibeureum Village.

With the development of tourism in Cibeureum Village, it has been able to change most people's livelihoods into a more modern heterogeneous society. The existence of stratification in society and the beginning of labor division in society are certainly characteristic of modern society or more complex society. After the development of tourism, of course, there is a lot that can be done by the people of Cibeureum Village to improve the economy of the people in various sectors of work, not only in relying on the agricultural se ctor, but the community can involve other things to support the tourism sector such as building restaurants, stalls, hotels, with the after math of the development of tourism. Herbert Spencer said that Multilined theories of evolution as a theory of community development stages in research results. Herbert Spencer described that the community's condition would develop from a livelihood system originally hunted into farming. Likewise, what happened in Cibeureum Village, from the results of the author's research, the community developed gradually from a livelihood system that started as farming people who now become workers in the tourism sector. It is because the community accepts the changes that have come to Cibeureum Village. Because these changes have brought the flow towards a more modern one, people feel helped in terms of economic improvement by tourism in Cibeureum Village. The changes that occur in Cibeureum Village certainly do not impact the community's livelihood sector but impact social changes that occur in the community due to the economic improvement in Cibeureum Village. People such as teachers and women who manage cleanliness are starting to be empowered by the Karang Taruna, the Karang Taruna gives them wages because Karang Taruna has more income because of the tourism sector in Cibeureum Village.

\section{CONCLUSION}

The condition of the people of Cibeureum Village was originally an agrarian society; people who daily depend on their income in the agricultural sector, livestock, and small traders. Initially, the life of the people of Cibeureum Village was the same as other village communities, namely, they often worked together and had a life together. However, after the tourism industry's existence, people began to switch from an agricultural society to a tourism industry community. Here the community begins to collaborate with tourism managers to develop tourism. For example, people have started to turn their yard into a parking area for tourists to increase their in come. In the social aspect, the people of Cibeureum Village, especially youth organizations, are empowered by tourism managers, they are included to work together so that youth organizations have sufficient income so that the youth organization can pay teachers and cleaning staff as a result of the benefits of working with tourism managers. Thus, the positive impact felt by the people of Cibeureum Village from the growing development of the tourism industry will certainly reduce poverty and unemployment rates in Cibeureum Village.

However, social change does not always run smoothly. There are negative impacts felt by the people of Cibeureum Village, such as heavy traffic, which affects farmers and other breeders to market their agricultural products because the road they are traveling on becomes congested and jammed accompanied by dirty air from vehicles coming to the location travel.

Concerning the ecologically-based tourism industry in Cibeureum Village, the researchers advise tourism management parties to conduct regular community empowerment programs, such as online business training and training on good harvest processing. The purpose of holding this program is expected to be able to increase the creativity and innovation of the people of Cibeureum Village, given that not all elements of society can be absorbed to work in the tourism concerned, of course, with the expertise possessed by the community in the future, so that people continue to have other creativity thanks to frequent the holding of these educational programs.

In addition, geo-trek development is needed in each of the Citarum sub-watershed in the future, while the proposed geotrek is adjusted to activities that can be carried out by tourists. Dry track geotrek and wet track geotrek can be made by geotourism destination managers in collaboration with communities, government, universities, and so on. Geotourism interpretation planning in geosites is carried out through the information board's narrative on the geosites and is also done online through the destination manager's sites. 
Community-based geotourism development in the Upper Citarum Sub-watershed needs to be done by providing training related to tourist destinations' development. The planning for the mitigation system for the Upper Citarum Zone geotourism destinations involves all stakeholders based on a community-based approach. Marketing planning for geotourism destinations in the Upper Citarum Zone from the local level or destination managers to the national level is linked and integrated to reduce marketing costs.

\section{REFERENCES}

Amir, A.F., Ghapar, A.A., Jamal, S.A., \& Ahmad, K.N. (2015). Sustainable tourism development: A study on community resilience for rural tourism in Malaysia. Procedia-Social and Behavioral Sciences, 168, 116-122. https://doi.org/10.1016/j.sbspro.2014.10.217

Board, M.A. (2005). Millennium ecosystem assessment. Washington, DC: New Island, 13.

Bouzekraoui, H., Barakat, A., Touhami, F., Mouaddine, A., \& El Youssi, M. (2018). Inventory and assessment of geomorphosites for geotourism development: A case study of Ait Bou Oulli valley (Central High-Atlas, Morocco). Area, 50(3), 331-343. https://doi.org/10.1111/area.12380

Brahmantyo, B. (2013). Geotourism in Indonesian Perspective. Proceedings HAGI-IAGI Joint Convention Medan, 28-31.

Dowling, R.K. (2011). Geotourism's global growth. Geoheritage, 3(1), 1-13. https://doi.org/10.1007/s12371-010-0024-7

Dowling, R.K. (2013). Global Geotourism - An Emerging Form of Sustainable Tourism. Czech Journal of Tourism, 2(2), 59-79. https://doi.org/10.2478/cjot2013-0004

Farsani, N.T., Coelho, C., \& Costa, C. (2011). Geotourism and geoparks as novel strategies for socio-economic development in rural areas. International Journal of Tourism Research, 13(1), 68-81. https://doi.org/10.1002/jtr.800

Gordon, J.E., \& Barron, H.F. (2013). The role of geodiversity in delivering ecosystem services and benefits in Scotland. Scottish Journal of Geology, 49(1), 41-58. https://doi.org/10.1144/sjg2011-465

Gray, M. (2004). Geodiversity: valuing and conserving abiotic nature. John Wiley \& Sons.

Gray, M. (2011). Other nature: geodiversity and geosystem services. Environmental Conservation, 38(3), 271-274. https://doi.org/10.1017/S0376892911000117

Gray, M., Gordon, J.E., \& Brown, E.J. (2013). Geodiversity and the ecosystem approach: the contribution of geoscience in delivering integrated environmental management. Proceedings of the Geologists' Association, 124(4), 659-673. https://doi.org/10.1016/j.pgeola.2013.01.003

Henriques, M.H., Canales, M.L., García-Frank, A., \& Gomez-Heras, M. (2019). Accessible geoparks in Iberia: a challenge to promote geotourism and education for sustainable development. Geoheritage, 11(2), 471-484. https://doi.org/10.1007/s12371-018-0300-5

Hjort, J., Gordon, J.E., Gray, M., \& Hunter, M.L. (2015). Why geodiversity matters in valuing nature's stage. Conservation Biology, 29(3), 630-639. https://doi.org/10.1111/cobi.12510

Hose, T.A. (1995). Selling the story of Britain's stone. Environmental Interpretation, 10(2), 16-17.

Jenkins, H., \& Ito, M. (2015). Participatory culture in a networked era: A conversation on youth, learning, commerce, and politics. John Wiley \& Sons.

Lazzari, M., \& Aloia, A. (2014). Geoparks, geoheritage and geotourism: opportunities and tools in sustainable development of the territory. GeoJournal of Tourism and Geosites, 13(1), 8-9. http://gtg.webhost.uoradea.ro/PDF/GTG-1-2014/1_1_special_number.pdf

Lovell, S. (2009). Participatory action research approaches and methods: Connecting people, participation and place-Edited by Sara Kindon, Rachel Pain and Mike Kesby. New Zealand Geographer, 65(2), 162-163.

McIntyre, A. (2007). Participatory action research, vol. 52, Sage Publications.

McKercher, B. (1993). The unrecognized threat to tourism: can tourism survive 'sustainability'? Tourism Management, 14(2), 131-136. https://doi.org/10.1016/0261-5177(93)90046-N

Melelli, L. (2014). Geodiversity: a new quantitative index for natural protected areas enhancement. Geojournal of Tourism and Geosites, 1(13), 27-37.

Melelli, S., Mihajlovic, M., \& Scaron, I. (2012). European policy for the promotion of inland waterway transport: A case study of the Danube River. African Journal of Business Management, 6(7), 2498-2507. https://doi.org/10.5772/26716

Newsome, D., \& Dowling, R. (2010). Setting an agenda for geotourism, vol. 4, Good Fellow Publishers: Oxford.

Newsome, D., Dowling, R., \& Leung, Y.F. (2012). The nature and management of geotourism: A case study of two established iconic geotourism destinations. Tourism Management Perspectives, 2-3, 19-27. https://doi.org/10.1016/j.tmp.2011.12.009

Olson, K., \& Dowling, R. (2018). Geotourism and cultural heritage. Journal of Geoconservation Research (GCR), 1(1), 37-41. https://doi.org/10.30486/GCR.2018.540021

Pereira, L.S., da Cunha, L.S. da, \& do Nascimento, M.A.L. (2018). Emergence of Geotourism Activity at João Pessoa Municipality and South Coast of Paraíba (Ne Brazil). Sustainable Geoscience and Geotourism, 1, 1-10. https://doi.org/10.18052/www.scipress.com/SGG.1.1

Schuler, D., \& Namioka, A. (1993). Participatory design: Principles and practices. CRC Press.

Shils, E. (2011). From Tradition. The Collective Memory Reader, 402-406. https://doi.org/10.1177/0048393107299685

Sungkar, A., \& Brahmantyo, B. (2013). Eco-Geotourism in Indonesia. In Ministry of Tourism and Creative Economy (Ed.), In Ecotourism and Sustainable Tourism Development in Indonesia: Potential, Lessons and Best Practice, 162-206.

Veal, A.J. (2017). Research methods for leisure and tourism. Pearson UK.

*** IUCN. (2012). Highlights of the 2012 IUCN World Conservation Congress. https://www.iucn.org/downloads/2012_congress_highlights_final_pxp.pdf

*** Interview with Ade, (a vegetable medicine trader) 5/5/2020.

*** Interview with Edik (a tourism manager), 5/5/2020.

*** Interview with Mustaqim, (a farmer), 5/5/2020.

*** Interview with Mustofa, (a member of Karang Taruna), 5/5/2020).

$* * *$ Interview with Supriatin, (a resident), 5/5/2020.

*** Interview with Taufik, (a tourism worker), 5/5/2020.

*** Interview with Yanto, (a farmer), 5/5/2020. 